Sains Malaysiana 51(1)(2022): 239-247

http://doi.org/10.17576/jsm-2022-5101-19

\title{
The Prevalence of Cytomegalovirus (CMV) Infection among Infants and Correlation between CMV PCR with Clinical Outcomes in a Tertiary Teaching Hospital in Malaysia \\ (Prevalens Jangkitan Sitomegalovirus (CMV) dalam Kalangan Bayi dan Korelasi antara CMV PCR dengan Hasil Klinikal di Hospital Pengajaran Tertier di Malaysia)
}

\author{
Norjihan Abdul Hamid, Nabilah Ismail, Alwi Muhd Besari @ Hashim, Suharni Mohamad \& Zeti \\ NORFIDIYATI SALMUNA*
}

\begin{abstract}
Congenital cytomegalovirus (cCMV) infection is the leading infectious cause of congenital hearing loss and neurodevelopmental disability. This study aimed to describe the prevalence and clinical manifestations of infants age 12 months and below with CMV infection in Hospital Universiti Sains Malaysia (Hospital USM) and to determine the correlation between CMV PCR with clinical outcomes. A total of 648 hospitalized infants with clinically suspected cases of cytomegalovirus infection admitted to Hospital USM from January 2018 to December 2018 were tested for anti-CMV IgM and IgG by electrochemiluminescence immunoassay method. The results suggestive of CMV infection were requested for the second serum sample at 2-4 weeks' interval together with plasma samples for CMV DNA viral load quantification by real-time PCR and maternal sample for serological analysis. Correlation of CMV viral load with clinical outcomes was analyzed using the point- biserial correlation. The results showed that the prevalence of acute CMV infection was $6.48 \%(42 / 648)$ and cCMV infection was $0.3 \%(n=2 / 648)$. The findings were as follows: acute CMV infection $(n=42)$, passive immunity $(n=113)$ and inconclusive $(n=41)$.) CMV hepatitis ( $p$-value $=0.018)$, rash $(p$-value $=0.043)$, presumed sepsis ( $p$-value $=0.044)$ and abnormal hearing ( $p$-value 0.031) were significantly associated with CMV status. Significant moderate correlation between CMV viral load and abnormal hearing assessment was observed. As a conclusion, CMV hepatitis, presumed sepsis, rash, and abnormal hearing were associated with the infant's CMV status. A significant correlation was found between CMV viral load and abnormal hearing.
\end{abstract}

Keywords: Cytomegalovirus; infants; PCR; prevalence; serology

\section{ABSTRAK}

Jangkitan sitomegalovirus kongenital (cCMV) adalah antara penyebab utama kehilangan pendengaran kongenital dan kecacatan perkembangan saraf. Kajian ini bertujuan untuk mengetahui prevalens dan manifestasi klinikal bayi berumur 12 bulan dan ke bawah dengan jangkitan CMV di Hospital Universiti Sains Malaysia (Hospital USM) dan untuk menentukan korelasi antara CMV PCR dengan hasil klinikal. Seramai 648 bayi yang dirawat di hospital dengan kes yang disyaki secara klinikal terdapat jangkitan sitomegalovirus yang dimasukkan ke Hospital USM dari Januari 2018 hingga Disember 2018 diuji untuk anti-CMV IgM dan IgG dengan kaedah elektrokemiluminesen immunoesei. Keputusan yang menunjukkan jangkitan CMV diminta untuk menghantar sampel serum kedua pada selang 2-4 minggu bersama dengan sampel plasma untuk viral load CMV DNA kuantifikasi dengan PCR masa nyata dan sampel ibu untuk analisis serologi. Korelasi antara $C M V$ viral load dengan hasil klinikal dianalisis menggunakan korelasi point-biserial. Keputusan menunjukkan prevalens jangkitan CMV akut adalah 6.48\% (42/648) dan jangkitan cCMV adalah 0.3\% $(n=2 / 648)$. Penemuannya adalah seperti berikut: jangkitan CMV akut $(n=42)$, imuniti pasif $(n=113)$ dan tidak meyakinkan $(n=41)$.) Hepatitis CMV (nilai $p$ $=0,018)$, ruam (nilai $p=0,043)$, disyakki sepsis (nilai-p $=0,044)$ dan pendengaran yang tidak normal (nilai-p 0,031) dikaitkan secara signifikan dengan status jangkitan CMV. Wujud hubungan yang sederhana signifikan antara CMV viral load dan pendengaran yang tidak normal. Kesimpulannya, hepatitis CMV, sepsis, ruam dan pendengaran yang tidak normal dikaitkan dengan status jangkitan CMV bayi. Hubungan korelasi yang signifikan didapati antara viral load CMV dan pendengaran yang tidak normal.

Kata kunci: Bayi; PCR; prevalens; serologi; sitomegalovirus 


\section{INTRODUCTION}

Cytomegalovirus (CMV) belongs to the $\beta$-herpesviridae subfamily and is recognized for its tendency to cause disease in immunocompromised patients, mainly transplant patients, patients with advanced HIV infection, and congenitally infected newborn (Spector et al. 2002). CMV infection in infants can happen in a divergent period of life, such as during the intrauterine period (prenatal or vertical infection), which may lead to congenital infection, during delivery (perinatal infection) or with breastmilk feeding during the postnatal period.

Infection in early pregnancy will lead to clinical manifestations such as intrauterine growth retardation, microcephaly, petechiae, thrombocytopenia, jaundice, chorioretinitis, or hepatosplenomegaly (Boppana et al. 2013). About 10-15\% of congenital CMV (cCMV) will bear with symptoms, but another $85-90 \%$ newborns with cCMV were asymptomatic. More than $90 \%$ of symptomatic infants will develop long-term outcomes such as sensorineural hearing loss (SNHL), impaired vision, developmental delay, cerebral palsy, and vision loss (Coll et al. 2009).

cCMV possesses a significant impact on developing countries due to high birth rates and high seroprevalence. The incidence of cCMV infection is in conjunction with the seroprevalence of cCMV antibodies in the community. Hence, this study aimed to determine the epidemiology, clinical manifestations, and clinical outcomes of infants with CMV infection in Hospital USM and to explore further the correlation between CMV viral load and the clinical outcomes of the infected infants.

\section{MATERIALS AND MEthods}

\section{STUDY PARTICIPANTS}

A total of 648 hospitalized infants with clinically suspected cases of cytomegalovirus infection admitted to Hospital USM from January 2018 to December 2018 were enrolled. Infants with first serum samples of IgM and $\mathrm{IgG}$ antibody titer suggestive of CMV infection were requested for the second serum sample at two to four weeks' interval together with plasma samples for CMV viral load and maternal sample for serological analysis. Out of these, 196 infants were chosen based on the inclusion and exclusion standard. The exclusion criteria were single serum samples from infants who had passed away, infants that started on acyclovir antiviral therapy before the first serum sample, and second serum sample sent more than four weeks' duration and infants with missing folders.

\section{DEFINITION OF VARIABLES}

Definition of acute CMV infection in infant is an active infection in a previously seronegative, a turn from negative to positive serologic testing (seroconversion) or the identification of CMV DNA in blood, urine, or saliva (Kimberlin et al. 2015a). The definition of passive immunity in CMV infection, according to $\mathrm{CDC}$, is the presence of CMV IgG in person less than 12 months old with a positive maternal sample of CMV IgG (CDC 2016). The definition of inconclusive in this study context is a seropositive sample without evidence of seroconversion or negative CMV DNA PCR, and no maternal serological sample sent.

To differentiate cCMV infection with postnatally acquired infection, virus isolation or CMV DNA PCR detection using urine or saliva within three weeks of birth was needed to confirm the diagnosis (Balcarek et al. 1993; Stagno 1986).

The definition of abnormal hearing assessment in CMV infection was quite challenging as it does not have a pathognomonic audiometric and can be either unilateral or bilateral hearing impaired, with impairment varying from unilateral high-frequency losses $(4-8 \mathrm{kHz}$ frequencies only) to intense bilateral losses (Fowler \& Boppana 2006). Therefore, the definition of the abnormal hearing referred to failed otoacoustic emission with tympanometry Type A (suggesting normal middle ear function) with auditory brainstem response of more than $20 \mathrm{dBnHL}$ on click stimulus. The brainstem response thresholds were defined as normal hearing: 0 to $20 \mathrm{~dB}$ thresholds and abnormal hearing $\geq 21 \mathrm{~dB}$ thresholds as the lowest intensity level wave $\mathrm{V}$ could be detected and replicated (Kimberlin et al. 2003). The instrument used for hearing assessment were portable battery-operated otoacoustic emission instruments, tympanometry, and an auditory brainstem response tool.

\section{SERA, PLASMA COLLECTION AND LABORATORY INVESTIGATION}

The Elecsys CMV IgG and IgM immunoassays (Roche, Germany) were used to screen the infant's serum sample for anti-CMV IgMs/IgGs the manufacturer's standard. Sera with $\mathrm{IgG}$ titers of $<0.5 \mathrm{IU} / \mathrm{mL}$ were reported as nonreactive for anti-CMV IgGs, $\mathrm{IgG}$ titers of $0.5-<1.0 \mathrm{IU} / \mathrm{mL}$ were reported as indeterminate, and IgG titers of $\geq 1 \mathrm{IU} /$ $\mathrm{mL}$ were reported as reactive. Whereas, CMV IgM results were reported in the cut-off index (COI - sample signal/ cut off). Samples positive for CMV IgM with COI of $<0.7$, $\geq 0.7$ but $<1.0$ and $\geq 1.0$ were reported as non-reactive, 
indeterminate, and reactive, respectively. Plasma samples for CMV viral load and maternal sample for CMV IgM/ $\mathrm{IgG}$ were requested with the second serum sample at two to four weeks interval.

The QIAamp MiniElute Virus Spin Kit (Qiagen, Limburg, Netherlands) was used to extract viral nucleic acid from $200 \mu \mathrm{L}$ of plasma. Following the manufacturer's instructions, CMV viral load was determined using the RealStar CMV PCR Kit 1.0 (Altona Diagnostics, Hamburg, Germany). Real-time quantitative PCR was done using the ABI Prism 7500 SDS (Applied Biosystems, Waltham, Massachusetts, USA). A standard calibration curve was then generated by the quantitation standard CMV DNA positive calibrators provided by the manufacturer. Viremia was defined as a measurable viral load, as per manufacturer's recommendations, and the viral load is presented as $\log _{10} \mathrm{IU} / \mathrm{mL}$ of peripheral blood.

\section{STATISTICAL ANALYSIS}

The statistical software, Statistical Package for Social Science (SPSS) version 24, was used to analyze the data obtained from both checklist and laboratory. The data with the dependent variables were analyzed with descriptive statistics to find out the prevalence of CMV infection among infants. Clinical demographics of CMV infection in infants were analyzed using Fisher's Exact test, MannWhitney U test, and Pearson Chi-Square. The correlation between CMV viral load with clinical outcomes of CMV infection among infants in HUSM was analyzed using Point-Biserial Correlation. A point-biserial correlation was utilized to calculate the intensity and direction of the association that exists between one continuous variable and one categorical variable.

\section{RESULTS}

The maternal seroprevalence of CMV was $74 \%$ $(\mathrm{n}=145 / 196)$ with the prevalence of $\mathrm{cCMV}$ infection was $0.3 \%(\mathrm{n}=2 / 648)$. The prevalence of acute symptomatic CMV infection among hospitalized infants clinically suspected to have CMV infection in Hospital USM was $6.48 \%$ (42/648). This result was shown in Figure 1. By referring to Figure 1, the screening results of the first infant's serum samples for CMV IgMs, and IgGs showed that $99.3 \%(\mathrm{n}=644 / 648)$ were sero-reactive for CMV. Only $0.61 \%(n=4 / 648)$ infants showed no serological evidence of CMV infection. Second serum samples for CMV serology and plasma for CMV PCR were requested from infants with the first serum sample of $\operatorname{IgM}$ and
IgG antibody titer suggestive of CMV infection. Out of 648 cases, only 196 cases that had paired sera samples or positive for CMV PCR were proceeded for further analysis: Categorization of the cases into three groups: Acute CMV infection $(n=42)$, passive immunity $(n=$ 113 ) and inconclusive $(n=41)$. Only 97 cases from 648 cases had plasma sent for CMV PCR test, and 39 were positive. These findings were showed in Figure 1. The medical records of these patients were traced.

Infants were classified as acute, passive immunity from mother and inconclusive by comparing the serological profiles of the first serum samples with the corresponding second serum samples, CMV DNA PCR, and mother's serum samples. The clinical finding data such as clinical manifestations, radiological, auditory and ophthalmological findings were acquired from the medical record and compared with the serological results and CMV DNA PCR to categorize the CMV infections into three groups: acute CMV infection $(n=42 / 196)$, passive immunity $(n=113 / 196)$ and inconclusive $(n=41 / 196)$ (Figure 2).

The prevalence of cCMV infection in our study was only $0.3 \%(n=2 / 648)$. We only received two samples within three weeks of life that were positive for CMV viral load that fulfill the laboratory diagnostic criteria of cCMV. The CMV viral load were positive for 39 out of 97 cases. The results were presented as $\log _{10} \mathrm{IU} / \mathrm{mL}$ and ranged from $1.80 \log _{10} \mathrm{IU} / \mathrm{mL}$ to $4.77 \log _{10} \mathrm{IU} / \mathrm{mL}$.

Clinical presentation for infants with acute CMV infection was summarized in Table 1. 80.6\% $(\mathrm{n}=158 / 196)$ infants presented in less than 21 days of age. The Median (IQR) age was 2 (13) days. Regarding racial distribution, most of them were Malays $97.9 \%(\mathrm{n}=186 / 196)$, followed by Chinese $1.02 \%(n=2 / 196)$ and others $1.02 \%(n=$ 2/196).

There were significant association between hepatitis ( $\mathrm{p}$-value $=0.018)$, rash $(\mathrm{p}$-value $=0.043)$, abnormal hearing assessment ( $p$-value $=0.031)$ and presumed sepsis ( $p$-value $=0.044)$ with the status of CMV infection. Most infants, $66.7 \%$ with acute infection, had CMV hepatitis compared to $33.3 \%$ in inconclusive and passive immunity groups. Hundred percent of infants with a rash had acute CMV infection. Only $12.5 \%$ of infants with acute CMV infection presented with sepsis than $87.5 \%$ who did not present with sepsis. Hundred percent of acute CMV infection infants had an abnormal hearing assessment. The clinical demographics were summarized in Table 2.

There was a significant moderate positive correlation between CMV viral load titer in acute CMV infection 
with an abnormal hearing assessment. There was a weak positive correlation between CMV viral load titer in acute CMV infection with abnormal ocular findings. The results were summarized in Table 3. Only two cases were diagnosed with cCMV as only two samples for PCR sent within three weeks of life and were treated with antivirals, either Ganciclovir or Valganciclovir.

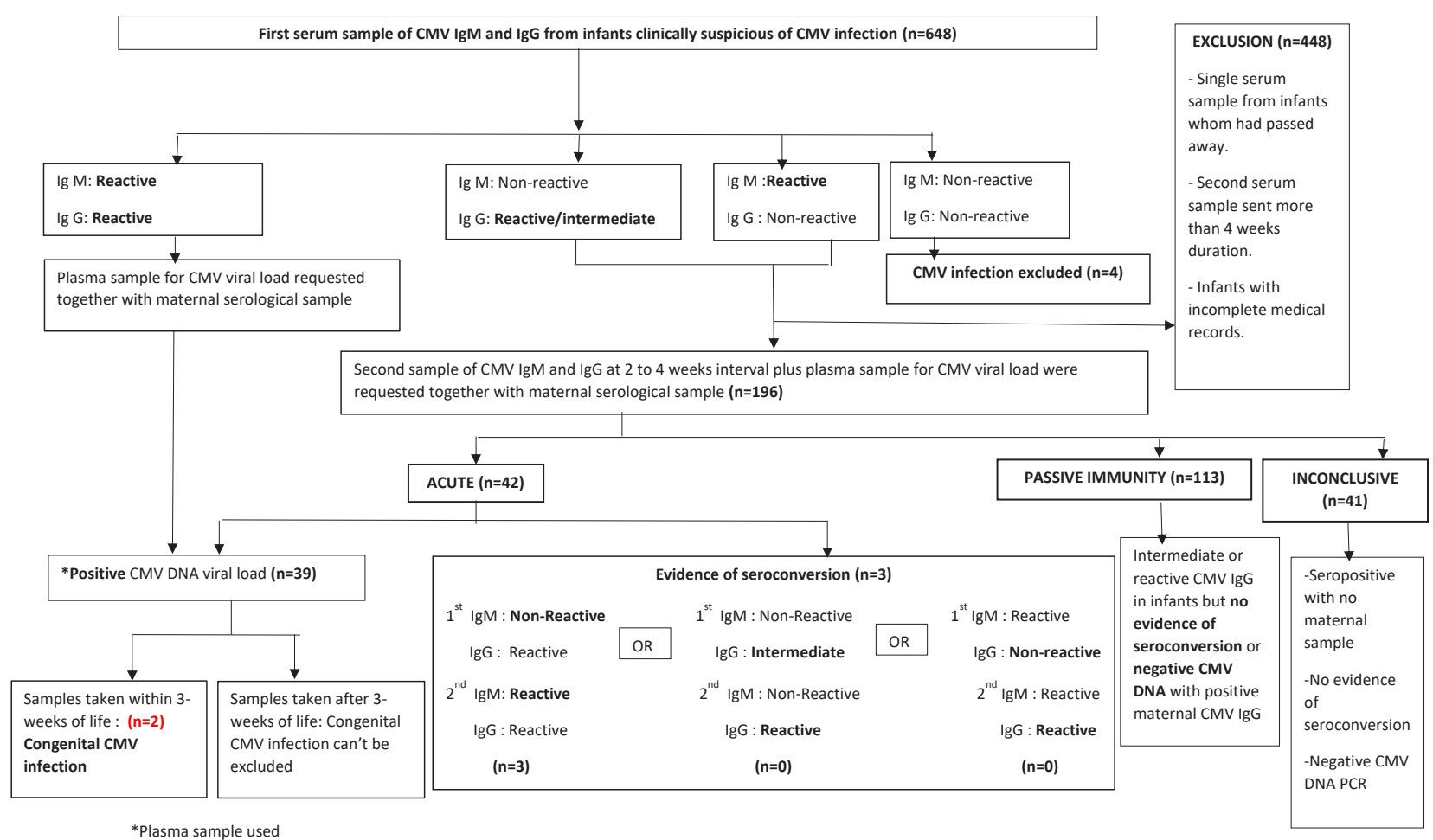

FIGURE 1. Flow chart on diagnostic algorithm of cytomegalovirus infection in infants

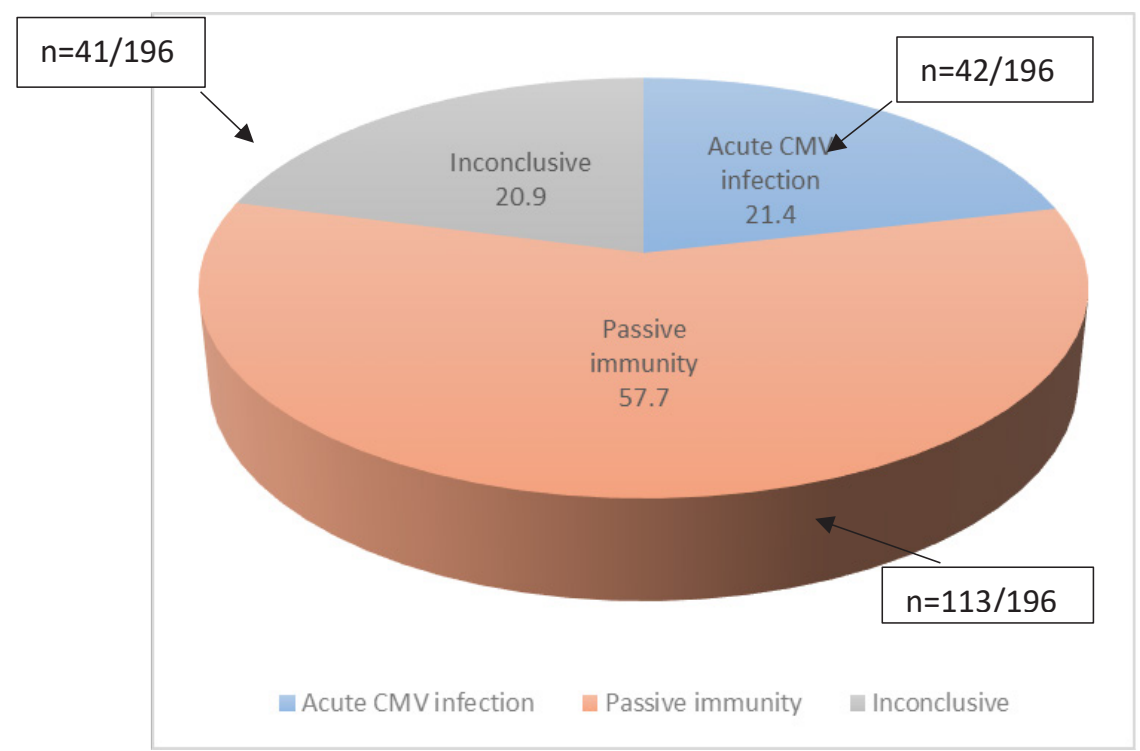

FIGURE 2. Distribution of the cases with positive CMV screening among symptomatic infants in HUSM $(n=196)$ 
TABLE 1. Clinical presentations of infants with acute CMV infection $(n=42)$

\begin{tabular}{lc}
\hline *Clinical presentations & $\mathrm{n}(\%)$ \\
\hline Small for gestational age (SGA)* & $27(64.2)$ \\
Indirect jaundice & $26(61.9)$ \\
Presumed sepsis & $9(21.4)$ \\
Abnormal hearing* & $4(9.5)$ \\
Hepatitis & $4(9.5)$ \\
Ocular problems* & $2(4.7)$ \\
Preterm & $2(4.7)$ \\
Rash* & $2(4.7)$ \\
Microcephaly & $1(2.3)$ \\
Cerebral calcification & $1(2.3)$ \\
Thrombocytopenia & $1(2.3)$ \\
\hline
\end{tabular}

One infant may have a combination of 2-3 clinical presentations

*SGA refers to birth weight below the $10^{\text {th }}$ percentile; *Abnormal hearing refers to failed otoacoustic emission with tympanometry Type A (suggesting normal middle ear function) together with auditory brainstem response of more than $20 \mathrm{dBnHL}$ on click stimulus; *Ocular problem refers to cataract and retinitis; *Rash refers to a non-specific maculopapular rash that can be due to immunologic reaction to CMV infection

TABLE 2. Clinical presentations and outcomes of CMV infections in infants $(n=196)$

\begin{tabular}{|c|c|c|c|c|c|}
\hline \multirow{2}{*}{$\begin{array}{l}\text { Clinical presentations } \\
\text { Acute } \\
42(21.4)\end{array}$} & & \multicolumn{2}{|c|}{ CMV infection $n(\%)$} & \multirow[t]{2}{*}{ Total } & \multirow[t]{2}{*}{${ }^{*} P$-value } \\
\hline & & \multicolumn{2}{|c|}{$\begin{array}{l}\text { Passive Immunity } \\
\text { and Inconclusive } \\
154(78.6)\end{array}$} & & \\
\hline \multirow[t]{2}{*}{ CMV Hepatitis } & Yes & $4(66.7)$ & $2(33.3)$ & 6 & $0.018^{\star}$ \\
\hline & No & $37(19.5)$ & $153(80.5)$ & 190 & \\
\hline \multirow[t]{2}{*}{ Rash } & Yes & $2(100)$ & $0(0)$ & 2 & $0.043^{\star}$ \\
\hline & No & $39(20)$ & $155(80)$ & 194 & \\
\hline \multirow[t]{2}{*}{ Presumed sepsis } & Yes & $8(12.5)$ & $56(87.5)$ & 64 & $0.044^{X^{2}}$ \\
\hline & No & $33(25)$ & $99(75)$ & 132 & \\
\hline \multirow[t]{2}{*}{ Prematurity } & Yes & $12(25.5)$ & $35(74.5)$ & 47 & $0.372^{\mathrm{X}^{2}}$ \\
\hline & No & $29(19.5)$ & $120(80.5)$ & 149 & \\
\hline \multirow[t]{2}{*}{ Microcephaly } & Yes & $1(20)$ & $4(80)$ & 5 & $1.000^{\ddagger}$ \\
\hline & No & $40(21)$ & 151(79) & 191 & \\
\hline
\end{tabular}




\begin{tabular}{|c|c|c|c|c|c|}
\hline Abnormal ultrasonography & Yes & $1(50)$ & $1(50)$ & 2 & $0.375^{*}$ \\
\hline findings & & & & & \\
\hline & No & $40(20.6)$ & $154(79.4)$ & 194 & \\
\hline Thrombocytopenia & Yes & $1(16.7)$ & $5(83.3)$ & 6 & $1.000^{\ddagger}$ \\
\hline & No & $40(21)$ & $150(79)$ & 190 & \\
\hline Small for gestational age & Yes & $26(18.8)$ & $112(81.2)$ & 138 & $0.270^{\mathrm{X}^{2}}$ \\
\hline (SGA) & & & & & \\
\hline & No & $15(25.9)$ & $43(74.1)$ & 58 & \\
\hline Indirect Jaundice & Yes & $26(24.1)$ & $82(75.9)$ & 108 & $0.383^{\mathrm{X}^{2}}$ \\
\hline & No & $16(18.2)$ & $72(81.8)$ & 88 & \\
\hline Outcomes & & & & & \\
\hline Abnormal hearing & & & & & \\
\hline assessment & Yes & $4(100)$ & $0(0)$ & 4 & $0.031^{*}$ \\
\hline & No & $15(38.5)$ & $24(61.5)$ & 39 & \\
\hline Abnormal ocular findings & Yes & $2(66.7)$ & $1(33.3)$ & 3 & $0.111^{*}$ \\
\hline & No & $39(20.2)$ & $154(79.8)$ & 193 & \\
\hline
\end{tabular}

*Significance level was set at $0.05,{ }^{\varepsilon}$ Mann-Whitney U test, ${ }^{\ddagger}$ Fisher`s Exact Test, ${ }^{\mathrm{X}^{2}}$ Pearson Chi Square

SGA refers to birth weight below the $10^{\text {th }}$ percentile; Rash refers to a non-specific maculopapular rash that can be due to immunologic reaction to CMV infection; Acute CMV infection refers to evidence of seroconversion or positive CMV DNA PCR; Abnormal ocular findings refer to cataract and retinitis; Abnormal hearing assessment refers to failed otoacoustic emission with tympanometry Type A (suggesting normal middle ear function) together with auditory brainstem response of more than $20 \mathrm{dBnHL}$ on click stimulus; Abnormal ultrasonography finding refers to cerebral calcification

TABLE 3. The correlation between viral loads and clinical outcomes of acute CMV infection

\begin{tabular}{|c|c|c|}
\hline \multirow{2}{*}{ Outcome } & \multicolumn{2}{|c|}{ Acute CMV infection } \\
\hline & $r$ & $* P$-value \\
\hline Abnormal hearing assessment & 0.571 & $0.002^{r}$ \\
\hline Abnormal ocular findings & 0.361 & $<0.001^{r}$ \\
\hline
\end{tabular}

$r$ Point biserial correlation, *Significance level was set at 0.05

Abnormal ocular findings refer to cataract and retinitis; Abnormal hearing assessment refers to failed otoacoustic emission with tympanometry Type A (suggesting normal middle ear function) together with auditory brainstem response of more than $20 \mathrm{dBnHL}$ on click stimulus 


\section{DISCUSSION}

The prevalence of cCMV ranges from $0.2 \%$ to $2 \%$ with an average of $0.65 \%$ (Arapović et al. 2020; Dollard et al. 2007). It was documented higher in the country with higher maternal seroprevalence (Lanzieri et al. 2014). However, a recent study published in 2020 found out that the prevalence of CCMV was inversely proportional to the maternal seroprevalence (Arapović et al. 2020). In our study, the maternal seroprevalence was $74 \%$ $(\mathrm{n}=145 / 196)$, with the prevalence of cCMV infection was only $0.3 \%(n=2 / 648)$, which was agreeable with a study in Bosnia and Herzegovina (Arapović et al. 2020). Compared to primary infection, secondary CMV infection or reactivation among pregnant women was accountable for most of the intrauterine CMV infection in Malaysia, but the primary infection was generally associated with neurological involvement (Balasubramaniam et al. 1994).

The reason for lower cCMV prevalence was possibly due to sampling time as not all blood collected for CMV PCR is within three weeks of life. The prevalence of acute symptomatic CMV infection among infants in HUSM was $6.48 \%$ (42/648). Our finding was lower than the prevalence of CMV infection which was $12.57 \%$ among neonates in an intensive care unit (NICU) in Egypt (Morgan et al. 2003).

CMV screening in pregnant women and neonates is not carried out as a routine microbiological workup in most countries, including Malaysia, and is only requested when CMV infection is suspected (Ross et al. 2012). Besides, the diagnosis is established by the serological method with a confirmation test by CMV DNA PCR. The diagnosis might be missed, especially in infants, by using the serological method. However, due to cost and the unavailability of PCR in all centers, screening with CMV IgM and $\operatorname{IgG}$ was done earlier. A study published in 2019 found that detection of CMV-IgM in neonatal serum had a sensitivity of $84.4 \%$ and a specificity of $99.3 \%$ to diagnose cCMV (Ohyama et al. 2019) and useful in the countries with limited health facilities to conduct a molecular test.

The first case of cCMV was diagnosed at day 1 of life with positive CMV DNA PCR by using plasma. He was presented with indirect jaundice, small for gestational age (SGA), dysmorphism, and hospitalized after birth to cover for sepsis. Cytogenetic analysis showed normal male karyotype (46, XY). The second case of cCMV was diagnosed at day 13 of life with positive CMV DNA PCR by using plasma. She was presented with indirect jaundice, SGA, thrombocytopenia, and macular rashes all over her face. She was treated with ganciclovir for 40 days. It is crucial to diagnose cCMV within three weeks of life so that prompt intervention can be taken to prevent sensorineural hearing loss and neurodevelopmental delay (Naing et al. 2016).

Majority of the children with CCMV were asymptomatic, and therefore the diagnosis was not made at birth. Small for gestational age (62.4\%) was the most predominant clinical finding seen in acute CMV infection in our study, followed by indirect jaundice $(61.9 \%)$. Meanwhile, jaundice was the most predominant clinical finding followed by hepatomegaly, pneumonitis, and prematurity among symptomatic neonates with serological evidence of congenital and perinatal HCMV infection which was agreeable with a study in Iraq (Alwan et al. 2016). Various disease conditions may cause jaundice. Among 42 infants with acute CMV infection, 26 had indirect jaundice ( 2 infants had underlying concomitant G6PD deficiency); 4 had direct jaundice (1 diagnosed with biliary atresia; 3 : transient cholestatic jaundice), and remaining 12 had no jaundice. Other symptoms that may be experienced by symptomatic infants are hepatosplenomegaly, microcephaly, petechiae, intrauterine growth restriction, and death (Naing et al. 2016).

A systematic review showed that $12.6 \%$ of newborns with cCMV would experience hearing loss either bilateral in symptomatic cases or unilateral in asymptomatic cases (Goderis et al. 2014). One study on Valganciclovir (VGCV) therapy for cCMVpatient showed that VGCV provide short-term improvement in hearing outcomes (McCrary et al. 2019) but another study showed that provision of VGCV for six months improve hearing and development in longer terms compared to 6 weeks' treatment (Kimberlin et al. 2015b).

Lack of awareness of cCMV among healthcare workers and the public can be due to three main factors. CMV infection is not recognized at birth due to the nature of the illness; most maternal and newborn infections were asymptomatic. Secondly, the sequelae of CMV infection are delayed. Lastly, most people assumed that cCMV born from women with a non- primary infection have a normal outcome (Manicklal et al. 2013).

In this study, we cannot rule out cCMV infection in 42 infants with acute CMV infection. A diagnosis of cCMV infection by detection of CMV DNA needs to be done within three weeks of life, as described by Bartlett et al. (2018) following guidelines from the Australian Paediatric Surveillance Unit in 1999. Majority of the 
CMV DNA viral load testing in our center was sent after three weeks of life, and these do not fulfil the definition of cCMV infection. Plasma infants were used for CMV DNA PCR instead of saliva due to the high risk of falsepositive as the virus was shed via breastmilk and may be transferred to infants' saliva during breastfeeding (Barkai et al. 2014).

Our study has several limitations. Paired sera could only be collected in one year due to a short study period. Other than that, because of a short study period, long-term follow-up for late sequelae outcomes such as sensorineural hearing loss and developmental delay could not be done. One study in 2018 only gave a general description of hearing loss as the duration and expectation for follow up for both conditions were uncertain (Bartlett et al. 2018).

\section{CONCLUSION}

The prevalence of CMV infection among infants in our center was comparable with one previous study. However, the prevalence of cCMV among infants was lower, possibly due to the under-diagnosis. Abnormal hearing assessment, presumed sepsis, CMV hepatitis, and rash were significantly associated with the status of CMV infection among infants. There was a significant correlation between CMV viral load with abnormal hearing assessment and abnormal ocular findings. Underdiagnosis and under-recognition of CMV infection among infants should be observed closely for early treatment and detection of the sequelae of congenital infection.

\section{ACKNOWLEDGEMENTS}

The authors would like to acknowledge the Director of the Universiti Sains Malaysia Hospital (HUSM) for permission to conduct the study and utilizing all the hospital facilities. The authors would like to thank En Amiruddin bin Abdullah from the Serology Laboratory Department of Medical Microbiology, Parasitology, and Pn. Noor Asmaliza Abdullah from Melocular Laboratory Department of Medical Microbiology and Parasitology for their guidance throughout the research period. The study protocol was approved by the Human Research Ethics Committee of Universiti Sains Malaysia (Approval number: USM/JEPeM/17110606). The approval for data collections from the patient's medical record was also obtained from the Director of Hospital USM. The medical information and data were kept confidential by the investigator. This work was supported by the Ministry of Higher Education (MOHE) and Universiti Sains Malaysia via research university grant (Grant no: 1001/PPSP/8012293) that has made this research project a success. ZNS, NI and AMB wrote the research proposal, NAH analyzed and interpreted the patient serological and molecular results regarding cytomegalovirus infection. SM advised on molecular aspects of the CMV testing, result troubleshooting and interpretation. NAH and ZNS were major contributors in writing the manuscript. All authors read and approved the final manuscript.

\section{REFERENCES}

Alwan, S.N., Arif, H.S., Al-Saffar, A.J., Kadhim, H.S., Wickes, B.L. \& Fu, J. 2016. Human cytomegalovirus infection among neonates with symptomatic congenital infections and birth defects. Iraqi Journal of Medical Sciences 14(4): 400407.

Arapović, J., Rajič, B., Pati, S., Brizić, I., Azinović, I., Šušak, B., Ostojić, M., Tutiš, B., Raguž, A.B., Tomić, V. \& Jonjić, S. 2020. Cytomegalovirus seroprevalence and birth prevalence of congenital CMV infection in Bosnia and Herzegovina: A single-center experience. The Pediatric Infectious Disease Journal 39(2): 140-144.

Balasubramaniam, V., Sinniah, M., Tan, D.S.K., Redzwan, G. \& Lo'man, S.G. 1994. The role of cytomegalovirus (CMV) infection in congenital diseases in Malaysia. Medical Journal of Malaysia 49(2): 113-116.

Balcarek, K.B., Warren, W., Smith, R.J., Lyon, M.D. \& Pass, R.F. 1993. Neonatal screening for congenital cytomegalovirus infection by detection of virus in saliva. Journal of Infectious Diseases 167(6): 1433-1436.

Barkai, G., Roth, D.A.E., Barzilai, A., Tepperberg-Oikawa, M., Mendelson, E., Hildesheimer, M. \& Kuint, J. 2014. Universal neonatal cytomegalovirus screening using saliva-report of clinical experience. Journal of Clinical Virology 60(4): 361-366.

Bartlett, A.W., Hall, B.M., Palasanthiran, P., McMullan, B., Shand, A.W. \& Rawlinson, W.D. 2018. Recognition, treatment, and sequelae of congenital cytomegalovirus in Australia: An observational study. Journal of Clinical Virology 108: 121-125.

Boppana, S.B., Ross, S.A. \& Fowler, K.B. 2013. Congenital cytomegalovirus infection: Clinical outcome. Clinical Infectious Diseases 57(suppl_4): S178-S181.

CDC. 2016. Laboratory Diagnosis of CMV Infection for Persons $\geq 12$ Months of Age 2016. United States: Centers for Disease Control and Prevention (CDC).

Coll, O., Benoist, G., Ville, Y., Weisman, L.E., Botet, F., Maurizio, M. Anceschi, T.W.P.I.W.G., Greenough, A., Gibbs, R.S. \& Carbonell-Estrany, X. 2009. Guidelines on CMV congenital infection. Journal of Perinatal Medicine 37(5): 433-445.

Dollard, S.C., Grosse, S.D. \& Ross, D.S. 2007. New estimates of the prevalence of neurological and sensory sequelae 
and mortality associated with congenital cytomegalovirus infection. Reviews in Medical Virology 17(5): 355-363.

Fowler, K.B. \& Boppana, S.B. 2006. Congenital cytomegalovirus (CMV) infection and hearing deficit. Journal of Clinical Virology 35(2): 226-231.

Goderis, J., De Leenheer, E., Smets, K., Van Hoecke, H., Keymeulen, A. \& Dhooge, I. 2014. Hearing loss and congenital CMV infection: A systematic review. Pediatrics 134(5): 972-982.

Kimberlin, D.W. 2003. National institute of allergy and infectious diseases collaborative antiviral study group. The Journal of Pediatrics 143(1): 16-25.

Kimberlin, D.W., Brady, M.T., Jackson, M.A. \& Long, S.S. 2015a. Red Book: 2015 Report of the Committee on Infectious Diseases. United States: American Academy of Pediatrics.

Kimberlin, D.W., Jester, P.M., Sánchez, P.J., Ahmed, A., Arav-Boger, R., Michaels, M.G., Ashouri, N., Englund, J.A., Estrada, B., Jacobs, R.F. \& Romero, J.R. 2015 b. Valganciclovir for symptomatic congenital cytomegalovirus disease. New England Journal of Medicine 372(10): 933-943.

Lanzieri, T.M., Dollard, S.C., Bialek, S.R. \& Grosse, S.D. 2014. Systematic review of the birth prevalence of congenital cytomegalovirus infection in developing countries. International Journal of Infectious Diseases 22: 44-48.

Manicklal, S., Emery, V.C., Lazzarotto, T., Boppana, S.B. \& Gupta, R.K. 2013. The "silent" global burden of congenital cytomegalovirus. Clinical Microbiology Reviews 26(1): 86-102.

McCrary, H., Sheng, X., Greene, T. \& Park, A. 2019. Long-term hearing outcomes of children with symptomatic congenital CMV treated with valganciclovir. International Journal of Pediatric Otorhinolaryngology 118: 124-127.

Morgan, M.A., Khalifa, N.A., Sherif, A. \& Rasslan, L.R. 2003. Prevalence of cytomegalovirus (CMV) infection among neonatal intensive care unit (NICU) and healthcare workers. The Egyptian Journal of Immunology 10(2): 1-8.

Naing, Z.W., Scott, G.M., Shand, A., Hamilton, S.T., van Zuylen, W.J., Basha, J., Hall, B., Craig, M.E. \& Rawlinson, W.D. 2016. Congenital cytomegalovirus infection in pregnancy: A review of prevalence, clinical features, diagnosis and prevention. Australian and New Zealand Journal of Obstetrics and Gynaecology 56(1): 9-18.

Ohyama, S., Fujioka, K., Fukushima, S., Abe, S., Ashina, M.,
Ikuta, T., Nishida, K., Matsumoto, H., Nakamachi, Y., Tanimura, K. \& Yamada, H. 2019. Diagnostic value of cytomegalovirus IgM antibodies at birth in PCR-confirmed congenital cytomegalovirus infection. International Journal of Molecular Sciences 20(13): 3239.

Ross, S.A., Novak, Z., Pati, S. \& Boppana, S.B. 2011. Overview of the diagnosis of cytomegalovirus infection. Infectious Disorders-Drug Targets 11(5): 466-474.

Spector, S.A., Davis, J.L. \& Singh, N. 2002. Cytomegalovirus - Infectious Disease and Antimicrobial Agents. 2nd ed. Pittsburgh: Antimicrobe.

Stagno, S. 1986. Cytomegalovirus infection: A pediatrician's perspective. Current Problems in Pediatrics 16(11): 633-667.

Norjihan Abdul Hamid, Nabilah Ismail \& Zeti Norfidiyati Salmuna*

Department of Medical Microbiology \& Parasitology

School of Medical Sciences

Universiti Sains Malaysia

16150 Kubang Kerian, Kelantan Darul Naim

Malaysia

Norjihan Abdul Hamid, Nabilah Ismail, Alwi Muhd Besari @ Hashim \& Zeti Norfidiyati Salmuna*

Hospital Universiti Sains Malaysia

16150 Kubang Kerian, Kelantan Darul Naim

Malaysia

Alwi Muhd Besari@ Hashim

Department of Internal Medicine

School of Medical Sciences

Universiti Sains Malaysia

16150 Kubang Kerian, Kelantan Darul Naim

Malaysia

Suharni Mohamad

School of Dental Sciences

Universiti Sains Malaysia

16150 Kubang Kerian, Kelantan Darul Naim

Malaysia

*Corresponding author; email: zetifidiyati@usm.my

Received: 24 August 2020

Accepted: 19 April 2021 